\title{
The role of biofuels in the future energy supply
}

\author{
Cite this: Energy Environ. Sci., 2013, 6, \\ 1077 \\ Received 17th December 2012 \\ Accepted 21st February 2013 \\ DOI: $10.1039 / c 3 e e 24403 b$
}

\section{Luis Caspeta, Nicolaas A. A. Buijs and Jens Nielsen*}

In recent years several different arguments have been raised against the use of biofuels and their role in our future energy supply. These arguments can be divided into issues related to costs, food versus fuel, and lack of sustainability. Here we address these three points and argue that biofuels represent an essential contribution to our future energy supply and more importantly will contribute to a reduction in carbon dioxide emissions.

\section{www.rsc.org/ees}

\section{Broader context}

Here we address three issues that, in recent years, have been raised as arguments against the use of biofuels and their role in our future energy supply. These issues are related to their costs of production, land use (or food versus fuel debate), and lack of sustainability. We argue that biofuels represent an essential contribution to our future energy supply and will contribute to a reduction in carbon dioxide emissions, and that most of the disapproval is related to the first generation of biofuels produced from edible feed stocks. We argue that giving up on the development and production of advanced biofuels, produced from biomass, is to neglect the opportunity of applying the advances in biotechnology, synthetic biology, systems biology, and metabolic engineering for the development of production processes for bio-based transportation fuels. By capitalizing on the advances in metabolic engineering it will be possible to develop efficient cell factories that can ensure a stable supply of transportation fuels for the future in addition to the substantial reduction of $\mathrm{CO}_{2}$ emissions at proper costs and hereby contribute to a reduction in global warming.

There is presently a scientific consensus about the environmental damage caused by emissions of carbon dioxide $\left(\mathrm{CO}_{2}\right)$ and other greenhouse gases (GHGs). This has resulted in an increasing pressure to decrease and eventually retire fossil fuels, which today not only represent our main source of energy but also represent the main source of $\mathrm{CO}_{2}$ emissions. For example, in 2009 fossil fuels provided $80 \%$ of the about 16 TeraWatts (TW) of energy used worldwide and the combustion of these released about 7.8 billion metric tons of carbon (GtC), i.e. $28.6 \mathrm{Gt}$ of $\mathrm{CO}_{2}{ }^{1,2}$ Due to the growth of population and average income, these numbers will increase, despite the introduction of technologies for more efficient energy usage, and the estimated energy demand by 2050 is at least 27.0 TW. $^{3}$ Today the atmospheric $\mathrm{CO}_{2}$ concentration is 394.5 parts per million by volume (ppmv), and the net accumulation has been progressively increased at a yearly rate of 1.03-2.13 ppmv during the last four decades (The Maua Loa Observatory). Thus, it will be expected to reach about 500 ppmv in 2050 if emissions remain unchecked. The biggest concern associated with global warming is the melting of ice sheets in the West Antarctic and in Greenland, which will result in a dramatic rise of the sea level, and changes in the thermohaline circulation (THC), which will result in dramatic climate changes. ${ }^{4}$ It has been suggested that stabilization of $\mathrm{CO}_{2}$ levels below 450 ppmv may

Department of Chemical and Biological Engineering, Chalmers University of Technology, Kemivägen 10, SE 41296 Gothenburg, Sweden. E-mail: nielsenj@ chalmers.se prevent the disintegration of the West Antarctic Ice Sheet and the shutdown of the THC. ${ }^{4}$ Hoffert and Covey (1992) suggested that concentrations of $550 \mathrm{ppmv}$, if sustained, could cause global warming comparable in magnitude but opposite in sign to the cooling of the world in the last Ice Age. ${ }^{5}$ Various scenarios to stabilize atmospheric $\mathrm{CO}_{2}$ concentrations at $450-650 \mathrm{ppmv}$ over the next few hundred years have been calculated, ${ }^{6,7}$ and these show that total annual $\mathrm{CO}_{2}$ emissions from 2050 and onwards should not exceed $6.0 \mathrm{GtC}$ in order to stabilize the atmospheric $\mathrm{CO}_{2}$ concentration at 450 ppmv by 2100 . In order to reach this level, it will be necessary to reduce actual emissions at an approximate rate of $\mathbf{4 4 . 2}$ million metric tons of carbon (MtC) per year, and assuming that the current proportions of oil, gas and coal will be maintained, this would require yearly replacement of approximately 8.0, 5.5, and 7.3 Gigawatts (GW) of these fossil fuels, respectively by carbon-constrained fuels. Additionally, it will also be necessary to produce 0.29 TW of carbon emission free energy in order to support the growth in energy consumption. Overall, we calculated that the amount of carbon-neutral fuel that has to be produced in 2050 has to be approximately $12 \mathrm{TW}$ in order to reach the $\mathrm{CO}_{2}$ emission target of 44.2 MtC. The Intergovernmental Panel on Climate Change (IPCC) Working Group III reported similar values. ${ }^{8}$

To overcome this grand challenge it will be necessary to implement a range of new $\mathrm{CO}_{2}$-constrained technologies for energy supply. ${ }^{3,9,10}$ The IPCC Working Group III has recently recommended the use of all available technologies to better reach environmental goals at lower economic costs. ${ }^{8}$ Although 
there are many alternatives for providing electricity and heat, i.e. nuclear, hydro, wind and solar, there are a few alternative options for transportation fuels (Fig. 1). There is currently much focus on electric cars, and their use is compelling in terms of energy efficiency, which is about $80 \%$ compared with about $20 \%$ for cars with internal combustion engines. However, the energy density in batteries is much lower than for liquid fuels ${ }^{11,12}$ and battery panels of $272-408 \mathrm{~kg}$ have to be used to cover distances of 145-400 km, which should compare with a standard gasoline tank of 45 liters weighing $50 \mathrm{~kg}$. Therefore reduction in cost and especially improvement in energy density are mandatory requirements for electric cars to become a major substitute for cars with internal combustion engines. ${ }^{8,11,12}$ There are also other issues with the implementation of electric cars such as mismatch with the current infrastructure and requirement of a stable supply of rare elements used in the batteries. ${ }^{9}$ For these reasons the National Petroleum Council (NPC) in the United States of America (USA) and the International Energy Agency (IEA) projected that electricity will be a moderate contributor to the transportation energy in 2050 (Fig. 2). ${ }^{13,14}$ Most likely, electricity will therefore only be used for short distance transportation using personal cars (city driving) as well as for locomotives, trains, trams and busses where electricity can be provided through existing overhead power lines or an electrified

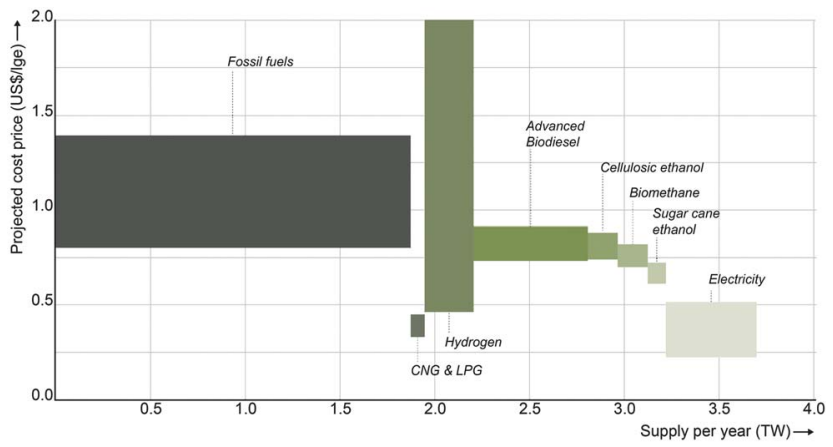

Fig. 2 Transportation energy supply for 2050 and projected retail prices. Prices are expressed in 2010 US\$ per liter gasoline equivalent (Ige). Sources: oil prices $^{14,19}$ compressed natural gas (CNG) and liquefied petroleum gas (LPG), ${ }^{20}$ hydrogen, ${ }^{21}$ electricity, ${ }^{19}$ advanced biodiesel, cellulosic ethanol, biomethane, and sugar cane ethanol. ${ }^{14}$

third rail (power lines required high investment), whereas for ships, aircrafts and trucks the use of internal combustion engines using diesels and jet fuels with an energy density of $12-13 \mathrm{~kW} \mathrm{~h} \mathrm{~kg}^{-1}$ is likely to be maintained for many years to come (Fig. 1).

Nowadays global consumption of liquid transportation fuels is about $2.9 \mathrm{TW}$ and these fuels are mainly derived from oil. ${ }^{1}$



Fig. 1 Renewable energy alternatives for transportation. (A) Current renewable alternatives to provide energy for transportation include biofuels from biomass and electricity from different sources including photovoltaics, wind, hydro and nuclear. (B) Comparison of the carbon intensity among fossil and renewable energy options data obtained from ref. 15-18. (C) Energy density in key fossil fuels and biofuels as well as in batteries. ${ }^{11,12}$ 
Between 1980 and 2008 there was a 31\% increase in oil consumption, but interestingly the known reserves increased comparably due to improved exploration and extraction techniques. ${ }^{9}$ Despite this fact oil prices have increased drastically in this period, and it has been argued that even though the oil reserves are increasing, access to cheap oil is limited at a supply of about 75 million barrels per day, and this causes dramatic increases in the oil price when the demand approaches this upper bound..$^{223}$ This should be seen in the context of the estimated requirement for a transportation fuel supply of around 110 million barrels per day in $2020 .^{23}$ Liquid transportation fuels can be derived from coal through the FischerTropsch process, but this is very energy intensive and has a very large $\mathrm{CO}_{2}$ footprint. Carbon capture and storage (CCS) can be used for decreasing $\mathrm{CO}_{2}$ emissions, but such a technology is still neither well developed nor economically competitive.,924 The discovery of large natural gas resources that can be extracted at low costs in the USA is expected to result in a wider use of liquefied natural gas (LNG) as a transportation fuel, and even though the investment is higher than for standard trucks, the payback time is, with the current price difference between diesel and LNG, only 3-4 years. ${ }^{9}$ The technology for use of LNG in internal combustion engines has been developed and implemented for busses, but a wider implementation will require investment in the necessary infrastructure. Furthermore, the combustion of natural gas will result in net $\mathrm{CO}_{2}$ emissions of about $443 \mathrm{~g} \mathrm{CO}_{2}$ per $\mathrm{kW}$ h (Fig. 1). Natural gas can

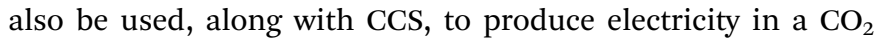
neutral way, but as mentioned above this technology is still not available cost competitively. ${ }^{24}$

Today biofuels represents about $2.7 \%$ of the global transportation energy $(\sim 0.12 \mathrm{TW}),{ }^{8}$ and it is dominated by ethanol (84.6 billion liters in 2011) and biodiesel derived from rapeseed or soybean oils (19.0 billion liters in 2011). Ethanol is primarily produced in the USA from corn (52.7 billion liters) and in Brazil from sugar cane (21.1 billion liters); both processes are often referred to as first generation bioethanol. In their forecast for transportation fuel usage in the USA by 2050, the National Petroleum Council (NPC) in the USA predicts that oil, natural gas and biofuels will dominate, but corn ethanol will be absent and substituted by lignocellulosic ethanol, generally referred to as second generation bioethanol (Fig. 2). ${ }^{\mathbf{1 3}}$

Despite the already extensive use of biofuels and their predicted wider use, criticism is often raised against the production and use of biofuels. This was particularly strong in a recent editorial in Angew. Chem., Int. Ed. by Dr Hartmut Michel with the title "The Nonsense of Biofuels". ${ }^{25}$ In the editorial Dr Michel argues that using plants for energy production is a poor use of the land as the upper efficiency of photosynthesis is $4.5 \%$ with a likely efficiency of about $1 \%$. He compares this with the $15 \%$ of the current solar panels and argues for the use of solar photovoltaic (PV) combined with the use of electric cars, as the use of land will be about 600 times more efficient than for the biomass-biofuels-combustion engine combination. Although these arguments are not debatable for ethanol and biodiesel produced from corn and soybean oil respectively, which have a net energy gain of $5.2 \mathrm{~mW} \mathrm{~h} \mathrm{ha}{ }^{-1}$ and $4.0 \mathrm{~mW} \mathrm{~h} \mathrm{ha}{ }^{-1}$, the case of ethanol from sugar cane or lignocellulose obtained from lowinput high-diversity grass is less dramatic, i.e. $\sim 120$ times less efficient with net energy gains of 26.0 and $28.0 \mathrm{~mW} \mathrm{~h} \mathrm{ha}$ respectively. ${ }^{15,16}$ Furthermore, biofuels produced from biomass waste, namely bagasse and other solid residues from the agroindustry, do not have a land-use issue as these materials are accumulated concomitant with the processing of crops, in addition to represent a potential solution to the disposal problems. Dr Michel also argues, in lines with others, that the bioethanol is not a $\mathrm{CO}_{2}$ neutral fuel. Besides the arguments against biofuels raised by Dr Michel, there are also often raised issues of costs and issues with use of agricultural land for production of fuels rather than food (food versus fuel issue). In the following we will address each of these issues and hereby hopefully demonstrate that much of the criticism is really linked to the current technologies, whereas emerging technologies will address all these issues and hereby represent attractive potential solutions to our future problems by ensuring sustainable supply of liquid transportation fuels.

An often raised argument against biofuels is the high cost and hence the requirement of governmental subsidy for ensuring cost-competitive production of biofuels. It is clear that biofuels cannot compete with fuels produced from conventional oil (e.g. oil supplied by the Organization of Petroleum Exporting Countries (OPEC)), whereas, depending on feedstock, they can be competitive with non-conventional oil derived from deep waters or the Arctic as well as oil extracted with enhanced oil recovery techniques (EOR oil). ${ }^{23}$ The transportation fuel supply curve for 2020 will therefore incorporate sugar cane ethanol as a biofuel that will not require subsidies, i.e. cheaper or in the same range of total-production cost as non-conventional oil derived fuels. Ethanol from corn, which is a less efficient process than sugar cane ethanol, will not be able to compete with any form of oil, and it will only survive on the market through subsidies and mandates. ${ }^{23}$ It is therefore expected that corn-ethanol will not be sustained after 2050 when cellulosic ethanol and advanced biodiesel will have an important participation in the supply curve (Fig. 2). Lignocellulosic ethanol, so-called second generation bioethanol, will be cost-competitive and is likely to replace existing corn based ethanol production in the next 10-15 years. ${ }^{14}$ Production of conventional biodiesel, i.e. biodiesel from vegetable oils, is also not cost competitive, and this is mainly due to the low energy yield per hectare $\left(\mathrm{mW} \mathrm{h} \mathrm{ha}^{-1}\right)$ of rapeseed and soybean cultivations (5.7 and $9.1 \mathrm{~mW} \mathrm{~h} \mathrm{ha}{ }^{-1}$ respectively compared with 18.8 $\mathrm{mW} \mathrm{h} \mathrm{ha}{ }^{-1}$ for corn and $36.12 \mathrm{~mW} \mathrm{~h} \mathrm{ha}^{-1}$ for sugar cane). ${ }^{26}$ Production of advanced biodiesel through microbial fermentation is with current technology quite expensive, but with a change to lignocellulosic feedstock use (or biomass feedstock) the cost of production will decrease dramatically. Thus, the argument of high cost for biofuels is an issue with two out of the three current technologies, i.e. bioethanol production from corn and biodiesel from rapeseed oil, whereas bioethanol from sugar cane is competitive in terms of production costs. But, with emerging technologies, such as biomass based production of ethanol and advanced biofuels, production of biofuels is likely to be cost competitive. 
Another criticism often raised is that biofuels do not contribute to a reduction in $\mathrm{CO}_{2}$ emissions compared with oilbased fuels, i.e. current biofuels are not $\mathrm{CO}_{2}$ neutral. As shown in Fig. 1B this is partly true when it comes to corn based ethanol as this only has an average of $12 \%$ lower carbon intensity than gasoline. ${ }^{17}$ This is mainly due to the large amounts of energy that have to be invested in the farming and for distillation of the ethanol. ${ }^{17}$ The two other types of biofuels currently being produced, however, result in significant reduction of $\mathrm{CO}_{2}$ emission compared with gasoline or diesel (Fig. 1B). Their use is not $\mathrm{CO}_{2}$ neutral but biodiesel from soybean has a $41 \%$ lower carbon intensity on average than diesel from oil and ethanol from sugar cane has a reduction of $60 \%$ compared with gasoline. ${ }^{16,17,27}$ The second generation of biofuels using biomass as a feedstock is expected to give a similar $60 \%$ reduction in carbon intensity. However, this can significantly increase and become $\mathrm{CO}_{2}$ negative if there is a utilization of lignocellulosic residues, e.g. utilization of forest, agricultural and livestock residues; short-rotation forest plantations; energy crops; the organic component of municipal solid waste; and other organic waste streams. Some calculations have shown that low-input highdiversity grassland biomass can provide greater reductions of greenhouse gas emissions, or even be carbon-negative because of net carbon dioxide sequestration (Fig. 1B).$^{15}$ However, it is important to perform proper evaluations of land-use change as the conversion of forest and grassland into a new cropland, like corn or switchgrass, can contribute to increased emissions, emphasizing the importance of the use of waste products, ${ }^{28}$ or restructuring current farming, e.g. change from tobacco to energy crops. Residues from the current most important crops accumulate approximately $2 \mathrm{TW},{ }^{29}$ and low-input high-diversity grassland biomass can easily provide an additional 2 TW. ${ }^{15,30,31}$ Transformation of this amount of energy into ethanol or advanced biofuels can yield between 0.7 and $1.6 \mathrm{TW}$, which is about $25-55 \%$ of the current energy use for transportation. In addition, this biomass may generate $0.8-1.8 \mathrm{~kW} \mathrm{~h} \mathrm{~L}^{-1}$ biofuel of electricity by burning the lignin ${ }^{32}$ (Fig. 1A). The use of 1 TW of biofuels produced from these resources can reduce $\mathrm{CO}_{2}$ emission by about $1.45 \mathrm{GtC}$ or even higher when considering the sequestration of carbon related to the use of abandoned and degraded land, which will almost alone ensure the required reduction of $\mathrm{CO}_{2}$ emissions. ${ }^{15}$

With a growing population and shift in dietary habits (towards eating more meat) there is an increased demand for land to be used for food production. It has therefore been argued that we should not be using land for biofuel production, i.e. a food versus fuel issue. In order to address this issue we evaluated the total biomass production in the World. The sun provides the earth with around 120000 TW per year and global photosynthesis uses part of this energy along with water and $\mathrm{CO}_{2}$ to produce around 100 billion tons of dry biomass annually. ${ }^{33}$ Approximately $6.5 \%$ of this biomass is diverged for human consumption, but one third is lost or wasted annually mostly in the industrialized world where this loss accounts for 95-115 kg per year per person due to mechanical damage, spillage during harvesting, degradation, loss of edible parts, and wastes during household consumption and managing in supermarkets. ${ }^{34}$ In low-income countries the loss accounts for 6-11 kg per year per person, and is mainly associated with technical, storage, packing and marketing limitations. ${ }^{34}$ Low-income countries are also limited in agronomic resources including technical assistance, low income per unit of land, migration of human labor, and earth erosion which limit the potential utilization of land for the production of food..$^{35,36}$ There are at present 35 countries requiring external assistance for food; most of them in the SubSaharan Africa and zones of Asia with severe civil conflicts. ${ }^{37}$ In recent years several commitments and programs have been facing agricultural, food supply, and rapid population growth problems in sub-Saharan Africa with the aim to decrease hunger and poverty as well as to improve livelihoods, social equity and sustainable development with Africa's own renewable means. ${ }^{35,38}$ This continent can be a potential exporter of cereals if political, agricultural and trade barriers get solved. ${ }^{39}$ Latin America is also a potential region for increasing the production of food and lignocellulosic biomass. Here there is a better, but still insufficient, infrastructure for financing and improving agriculture to better exploit the potential of this region. ${ }^{36}$ The former considerations are only related to the efficient use of arable land in lowincome countries, but there is a vast region of exhausted and low quality land extended of about 385-472 million hectares around the world that can be used for the cultivation of low-input, perennial grasses. ${ }^{29}$ Cultivation of plants of the Agavaceae family, which can grow in arid and degraded lands, has for example been considered an important option for food supply and the agave bagasse can be used for biofuel production. ${ }^{\mathbf{4 0}}$ Resolving problems of food waste, losses, production and distribution can be sufficient to ensure future food supply, while residues from the related agro-industrial activities can be used for biofuel production. Thus, there is basically no food versus fuel issue if the right infrastructure is implemented for handling of agricultural products.

From our arguments above it is quite clear that much of the criticism raised against biofuels is related to the current biofuel production, in particular corn ethanol and vegetable biodiesel. However, these processes are not likely to be part of the future biofuel industry (Fig. 2), which is moving towards the production of second generation bioethanol and advanced biofuels. The production of second generation bioethanol using biomass is much driven from a cost perspective and the terms for fitting technical improvements and feedstock-sustainability milestones are between 5 and 25-35 years respectively. ${ }^{14}$ However, if biofuel use will be expanded, there is a need for production of advanced biofuels. Ethanol is in fact not a good fuel as it has a


and it is only produced due to the very high efficiency of the conversion of sugars to ethanol by yeast fermentation. However, there is much interest in advanced biofuels that can fit even better into the current infrastructure, and ensure blending to high levels or even completely replace fossil derived transportation fuels (Fig. 1C). Butanol $\left(10.0 \mathrm{~kW} \mathrm{~h} \mathrm{~kg}^{-1}\right)$ is one example of advanced biofuel with improved characteristics, and currently two companies, Butamax (a Dupont-BP joint venture) and Gevo, are aiming at developing commercial butanol production. Other high density biofuels, called advanced 
biodiesels, are farnesane $\left(12.8 \mathrm{~kW} \mathrm{~h} \mathrm{~kg}^{-1}\right)$, fatty-acyl ethyl esters (11.25 kW h kg$\left.{ }^{-1}\right)$, and olefins (13.08 $\mathrm{kW} \mathrm{h} \mathrm{kg}^{-1}$ ). These biodiesels are being developed, tested and produced at the pilot scale by companies like Amyris, LS9 and Solazyme, respectively. Farnesane meets the ASTM D975 diesel standard and has received EPA certification to be blended at up to $35 \%$ with petroleum diesel - up to $15-20 \%$ is normally recommended for conventional biodiesel. It is also claimed that the other advanced biodiesels can be used in existing engines without modification as have been evaluated in naval ships, for example. Therefore, with the current developments of technologies for the production of advanced biofuels, demonstration of their economic feasibility is going to take between 8 and 20 years, and we are therefore likely to first see implementation sometime between 2020 and $2030 .^{14,41}$ These developments away from corn based ethanol and vegetable biodiesel and towards biomass derived ethanol and advanced biofuels are clearly supported by a number of reports. . $^{8,13,14,23,41,42}$

Advanced biofuels produced from lignocellulose can positively impact current concerns about the use of biofuels, breaking the barriers for their full integration in the current end-used technology - internal combustion engines. These technologies, called conventional transportation, will not suddenly change to other technologies based on electricity or hydrogen, which will require a gradual introduction since it requires the development of many sectors, i.e. production of advanced transportation engines and related industries of materials, components, control systems, installers, and business services. ${ }^{24,41}$ This kind of growth and diffusion of technology requires a considerable amount of time (between 2 and 7 decades ${ }^{24}$ ). Thus solar PV technologies, which nowadays account for about 0.04 TW (Renewables 2011), have been predicted to reach between 0.2 and 6.9 TW by 2050 based on historical growth. ${ }^{24}$ This is to compare with the predicted increased use of biofuels from $0.12 \mathrm{TW}$ in 2011 to between 1.2 and 7.4 TW by $2050 . .^{13,41}$

Advances in biofuel development and production not only stay at the development and optimization of technologies for the conversion of lignocellulose to the desired fuel, some research groups are currently working on the development of less-recalcitrant lignocellulosic materials to decrease pretreatment efforts and costs for the conversion of biomass into fermentable sugars by hydrolysis. ${ }^{43-45}$ Increase of photosynthetic capacity by replacing photosystem I by a new reaction center, with farther-red-absorbing pigments, can double the length of wave absorption, ${ }^{33,46}$ whilst engineering of the ribulose-1,5-bisphosphate (RuBP) carboxylase/oxygenase can increase $\mathrm{CO}_{2}$ assimilation. ${ }^{47,48}$ Furthermore, displaying hydrolytic activities in cells could lead to the generation of an integrated process that can convert lignocellulose to biofuels with one unit operation, with the concomitant decrease in production costs. ${ }^{49,50}$ Recently, an electro-microbial process for the conversion of sunlight and $\mathrm{CO}_{2}$ into alcohols has been reported. ${ }^{51}$ Much more advances have been generated in the last decade for redirecting the economy towards a bio-based economy. Ignoring the development and production of biofuels is to give up on the opportunity of applying the whole range of biotechnological applications (i.e. synthetic biology, systems biology, and metabolic engineering) to tackle the big problem of ensuring stable supply of transportation fuels for the future and at the same time reduce $\mathrm{CO}_{2}$ emissions at proper costs and hereby contribute to a reduction in global warming.

\section{Conflict of interest}

The authors declare no conflict of interest.

\section{Acknowledgements}

The authors acknowledge financial support from the European Research Council (grant no. 247013), Vetenskapsrådet and FORMAS.

\section{References}

12011 Key World Energy Statistics, The International Energy Agency (EIA), 2011, http://www.iea.org/publications/free publications/publication/key_world_energy_stats-1.pdf.

$22011 \mathrm{CO}_{2}$ Emissions from Fuel Combustion, The International Energy Agency (EIA), 2011, http://www.iea. org/co2highlights/co2highlights.pdf.

3 N. S. Lewis and D. G. Nocera, Proc. Natl. Acad. Sci. U. S. A., 2006, 103, 15729-15735.

4 B. C. O'Neill and M. Oppenheimer, Science, 2002, 296, 19711972.

5 M. I. Hoffert and C. Covey, Nature, 1992, 360, 573-576.

6 T. M. L. Wigley, R. Richels and J. A. Edmonds, Nature, 1996, 379, 240-243.

7 T. Houghton and Working group I, in Climate Change 1994: Radiative Forcing of Climate Change and an Evaluation of the IPCC 1992 Is92 Emission Scenarios, Cambridge Univ. Press, UK, 1st edn, 1995, pp. 233-304.

8 O. Edenhofer, R. Pichs Madruga, Y. Sokona, K. Seyboth, P. Eickemeier, P. Matschoss, G. Hansen, S. Sadner, S. Schlömer, T. Zwickel and C. von Stechow, in Renewable Energy Sources and Climate Change Mitigation: Special Report of the Intergovernmental Panel on Climate Change, Cambridge University Press, UK, 2012.

9 S. Chu and A. Majumdar, Nature, 2012, 488, 294-303.

10 M. I. Hoffert, K. Caldeira, G. Benford, D. R. Criswell, C. Green, H. Herzog, A. K. Jain, H. S. Kheshgi, K. S. Lackner, J. S. Lewis, H. D. Lightfoot, W. Manheimer, J. C. Mankins, M. E. Mauel, L. J. Perkins, M. E. Schlesinger, T. Volk and T. M. L. Wigley, Science, 2002, 298, 981-987.

11 M. M. Thackeray, C. Wolverton and E. D. Isaacs, Energy Environ. Sci., 2012, 5, 7854-7863.

12 V. Etacheri, R. Marom, R. Elazari, G. Salitra and D. Aurbach, Energy Environ. Sci., 2011, 4, 3243-3262.

13 Advancing Technology for America's Transportation Future, The National Petroleum Council (NPC), 2012, http://www. npc.org/FTF-report-080112/FTF_Report_Summary-080112. pdf.

14 Technology Roadmap: Biofuels for Transport, The International Energy Agency (IEA), 2011, http://www. 
iea.org/publications/freepublications/publication/biofuels_ roadmap.pdf.

15 D. Tilman, J. Hill and C. Lehman, Science, 2006, 314, 15981600.

16 J. Goldemberg, Biotechnol. Biofuels, 2008, 1, 1-7.

17 J. Hill, E. Nelson, D. Tilman, S. Polasky and D. Tiffany, Proc. Natl. Acad. Sci. U. S. A., 2006, 103, 11206-11210.

18 D. Weisser, Energy, 2007, 32, 1543-1559.

19 Preliminary Analysis of the Waxman-Markey Discussion Draft: The American Clean Energy and Security Act of 2009 in the 111th Congress, The Enviromental Protection Agency (EPA), 2009, http://www.iges.or.jp/en/cp/pdf/activity 20090511/session_3-daigneault.pdf.

20 D. Montgomery, R. Baron, P. Bernstein, S. Bloomberg, K. Ditzel, L. Lane, A. Smith, S. Tuladhar and M. Yuan, Impact on the Economy of the American Clean Energy and Security Act of 2009 (H.R.2454), CRA International, 2009, http://epw.senate.gov/public/index.cfm?FuseAction=Files. View\&FileStore_id=8230a041-2d13-4812-b5ed-ea9b2965faa0.

21 R. G. Lemus and J. M. Martínez-Duart, Int. J. Hydrogen Energy, 2010, 35, 3929-3936.

22 J. Murray and D. King, Nature, 2012, 481, 433-435.

23 H. Trépant, R. Kombargi, L. Hoteit, H. Nordahl, The Upstream Survivors of 2009 How to Live to Tell the Tale, Booz\&Co. 2009, http://www.booz.com/media/uploads/Up stream_Survivors_2009.pdf.

24 C. Wilson, Meta-Analysis of Unit and Industry Level Scaling Dynamics in Energy Technologies and Climate Change Mitigation Scenarios, International Institute for Applied Systems Analysis (IIASA), Laxenburg, Austria, 2012.

25 H. Michel, Angew. Chem., Int. Ed., 2012, 51, 2516-2518.

26 M. Johnston, J. A. Foley, T. Holloway, C. Kucharik and C. Monfreda, Environ. Res. Lett., 2009, 4, 014004, DOI: 10.1088/1748-9326/4/1/014004.

27 I. C. Macedo, J. E. A. Seabra and J. E. A. R. Silva, Biomass Bioenergy, 2008, 32, 582-595.

28 T. Searchinger, R. Heimlich, R. A. Houghton, F. Dong, A. Elobeid, J. Fabiosa, S. Tokgoz, D. Hayes and T.-H. Yu, Science, 2008, 319, 1238-1240.

29 R. Lal, Waste Manag., 2008, 28, 747-758.

30 S. Chris, Curr. Biol., 2007, 17, R115-R119.

31 J. E. Campbell, D. B. Lobell, R. C. Genova and C. B. Field, Environ. Sci. Technol., 2008, 42, 5791-5794.

32 D. Kumar and G. Murthy, Biotechnol. Biofuels, 2011, 4, 27.

33 J. Barber, Chem. Soc. Rev., 2009, 38, 185-196.

34 J. Gustavsson, C. Cederberg, U. Sonesson, R. van Otterdijk and A. Meybeck, Global Food Losses and Food Waste, The Food and Agriculrure Organization (FAO) of the United Nations, Rome, 2011.

35 Regional Strategic Framework for Africa 2010-2015, The Food and Agriculrure Organization (FAO), 2008, http:// www.fao.org/docrep/013/am054e/am054e00.pdf.
36 Agricultural Insurance in Latin America: Developing the Market, The Worl Bank (WB), 2010, http://siteresources worldbank.org/FINANCIALSECTOR/Resources/Agricultural_ insurance_in_LAC_web_FINAL.pdf.

37 Crop Prospects and Food Situation, The Food and Agriculrure Organization (FAO), 2012, http://www.fao.org/ docrep/015/al985e/al985e00.pdf.

38 International Assessment of Agricultural Knowledge, Science and Technology for Development, Sub-Saharan Africa Report, 2009, http://www.agassessment.org/reports/ IAASTD/EN/Agriculture\%20at\%20a\%20Crossroads_Global \%20Report\%20(English).pdf.

39 Africa Can Help Feed Africa: Removing Barriers to Regional Trade in Food Staples, The World Bank (WB), 2012, http:// www.worldbank.org/en/news/2012/10/24/africa-can-feed-itselfearn-billions-avoid-food-crises-unblocking-regional-food-trade.

40 H. M. Nuñes, L. F. Rodríguez and M. Khanna, GCB Bioenergy, 2011, 3, 43-57.

41 K. Riahi and F. Dentener, et al., in Global Energy AssessmentToward a Sustainable Future: Energy Pathways for Sustainable Development, Cambridge University Press, Cambridge, UK, ch. 17, 2012, pp. 1203-1306.

42 P. Fairley, Nature, 2011, 474, S2-S5.

43 A. Eudes, A. George, P. Mukerjee, J. S. Kim, B. Pollet, P. I. Benke, F. Yang, P. Mitra, L. Sun, Ö. P. Çetinkol, S. Chabout, G. Mouille, L. Soubigou-Taconnat, S. Balzergue, S. Singh, B. M. Holmes, A. Mukhopadhyay, J. D. Keasling, B. A. Simmons, C. Lapierre, J. Ralph and D. Loqué, Plant Biotechnol. J., 2012, 10, 609-620.

44 C. Fu, J. R. Mielenz, X. Xiao, Y. Ge, C. Y. Hamilton, M. Rodriguez, F. Chen, M. Foston, A. Ragauskas, J. Bouton, R. A. Dixon and Z.-Y. Wang, Proc. Natl. Acad. Sci. U. S. A., 2011, 108, 3803-3808.

45 B. S. Dien, D. J. Miller, R. E. Hector, R. A. Dixon, F. Chen, M. McCaslin, P. Reisen, G. Sarath and M. A. Cotta, Bioresour. Technol., 2011, 102, 6479-6486.

46 R. E. Blankenship, D. M. Tiede, J. Barber, G. W. Brudvig, G. Fleming, M. Ghirardi, M. R. Gunner, W. Junge, D. M. Kramer, A. Melis, T. A. Moore, C. C. Moser, D. G. Nocera, A. J. Nozik, D. R. Ort, W. W. Parson, R. C. Prince and R. T. Sayre, Science, 2011, 332, 805-809.

47 R. J. Spreitzer and M. E. Salvucci, Annu. Rev. Plant Biol., 2002, 53, 449-475.

48 I. Andersson and A. Backlund, Plant Physiol. Biochem., 2008, 46, 275-291.

49 I. Muñoz-Gutiérrez, R. Oropeza, G. Gosset and A. Martinez, J. Ind. Microbiol. Biotechnol., 2012, 39, 1141-1152.

50 L.-H. Fan, Z.-J. Zhang, X.-Y. Yu, Y.-X. Xue and T.-W. Tan, Proc. Natl. Acad. Sci. U. S. A., 2012, 109, 13260-13265.

51 H. Li, P. H. Opgenorth, D. G. Wernick, S. Rogers, T.-Y. Wu, W. Higashide, P. Malati, Y.-X. Huo, K. M. Cho and J. C. Liao, Science, 2012, 335, 1596. 